\title{
Chemical Studies on Tobacco Smoke \\ v. Quantitative Determination of Chlorinated Hydrocarbon Insecticlese In Cigarette Tobacco and its Smoke*
}

\author{
by D. Hoffmann and G. Rathkamp \\ Division of Environmental Cancerigenesis, Sloan-Kettering Institute for Cancer Research, \\ New York, New York
}

Bioassays on mouse skin with fractions of cigarette smoke condensate have demonstrated that the neutral subfraction BI has the highest carcinogenic as well as the highest tumor initiating activity $(10,21)$. BI amounts to about $0.6 \%$ of the whole smoke condensate. Certain chlorinated hydrocarbon insecticides and some of their thermic decomposition products belong to the components so far identified in this fraction (11).

During the last decade several investigators have reported on the presence of chlorinated insecticides in tobacco and tobacco smoke $(5,8,19,21)$. These compounds were 1,1,1-trichloro2,2-bis(p-chlorophenyl)ethane [DDT], 1,1-dichloro-2,2-bis(p-chlorophenyl)ethane [DDD], and $1,2,3,4,10,10$-hexachloro-6,7-epoxy-1,4,4a, 5,6,7,8,8a-octahydro-i, ,4-endo-endo-5,8-dimethanonaphthalene [endrin]. Mold and Walker, and later also other investigators identified 1-chloro-2,2-bis(p-chlorophenyl)ethylene [DDM] in cigarette smoke $(5,15)$. The analytical methods utilized for the determination of these compounds were colorimetric and spectroscopic procedures and, only lately, also gas chromatography with electron capture detectors. The reported content in the

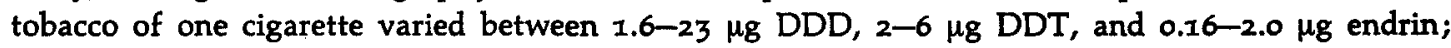
the values for cigar, pipe and chewing tobacco, and snuff varied between 4.3-44 ppm DDD and $0.2-1.3 \mathrm{ppm}$ endrin $(5,21)$. Guthrie and Bowery calculated a recovery of $10-20 \%$ DDD and $20-30 \%$ endrin in the mainstream smoke of a cigarette (5). One study estimated that upon inhalation the smoker retains about $70 \%$ of the DDD present in the cigarette smoke ( 1 ).

This communication presents data on the identification and quantitative analysis of chlorinated insecticides in cigarette tobacco, mainstream cigarette smoke, and the neutral fraction BI. The findings include data on some decomposition products of chlorinated insecticides.

\section{METHODS AND MATERIAL}

\section{Reference Compounds}

DDD; 1,1 -dichloro-2-(o-chlorophenyl)-2-(p-chlorophenyl)ethane [o,p-DDD]; 1,1-dichloro-2-(m-chlorophenyl)-2-(p-chlorophenyl)ethane [m,p-DDD]; DDT, and 1,1,1-trichloro-2-(0-chlorophenyl)-2(p-chlorophenyl)ethane [o,p-DDT] were purchased from the Aldrich Chemical Company (Milwaukee, Wisconsin). The compounds were twice purified on aluminum oxide (Woelm, neutral, activity II), and finally recrystallized from ethanol. 1,1-dichloro-2,2-bis(p-chlorophenyl)ethylene [DDE] and endrin were given generously by the Food and Drug Administration, Washington, D. C. DDM was synthesized from DDD according to Haller et al. (7) on a $200 \mathrm{mg}$ scale and resulted in a $77 \%$ yield after repeated column chromatography on Florisil (mesh 60-100, Fisher Scientific Co., New York) and recrystallization from methanol (m. p. 66-67 $\mathrm{C}$ ).

* This study was supported by American Cancer Society Grant E-231, and in part by N.C.I. Grant CA-08748. Received for publication: 11th March, 1968. 


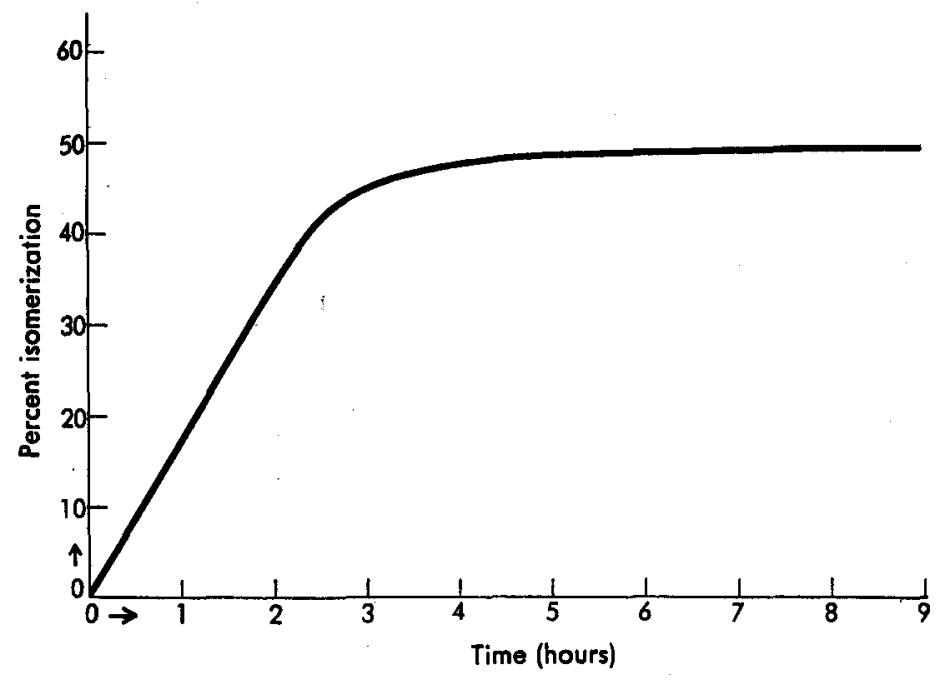

Rale of isomerization of (0.05 molar methanol solution)

Trans-4,4'-dichlorostilbene [DCS] was synthesized according to Lutz and Murphey (13) from $56 \mathrm{~g}$ p-chlorobenzaldehyde and the Grignard reagent of $24 \mathrm{~g} \mathrm{Mg}$ and $75 \mathrm{~g} \mathrm{p}$-chlorobenzylchloride. The impure, oily 1,2-di(p-chlorophenyl)ethanol was heated with $1 \mathrm{ml}$ of $48 \%$ hydrobromic acid for 15 minutes at about $230^{\circ} \mathrm{C}$. The neutral portion of the reaction product was chromatographed on aluminum oxide (Woelm, neutral, activity II) and the DCScontaining fraction was rechromatographed. This purified DCS was recrystallized from toluene. The overall yield was $52 \%$ and the melting point $176.5-177^{\circ} \mathrm{C}$.

All purification steps as well as analytical procedures for the determination of insecticides were undertaken in a laboratory illuminated by yellow light (no radiation below $450 \mathrm{~m} \mu$ ). Reference compounds and materials for the analyses were stored in brown bottles.

Cis-4,4'-dichlorostilbene [cis-DCS]

Preliminary studies revealed an "aging effect" for trans-4,4'-dichlorostilbene [DCS]. This effect is observed for DCS-solutions with or without exposure to oxygen under the influence of sun-light and of light from fluorescent tubes but does not occur in yellow light. "Aged" DCS-

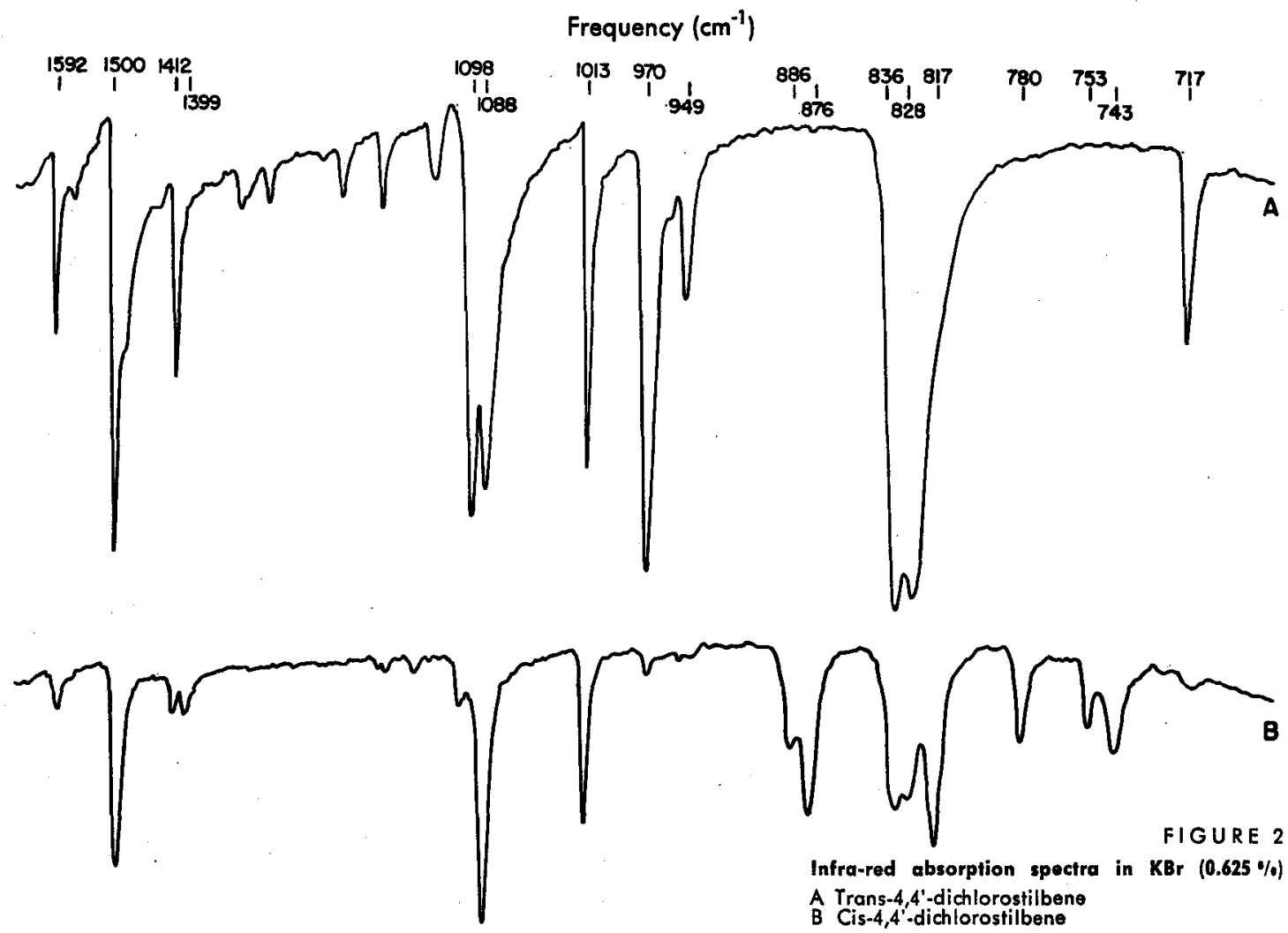


solutions show a new peak in their gas chromatogram and one may assume that this reflects a photoisomerization of trans-DCS to cis-DCS, similar to that known to occur with transstilbene (2). Figure 1 presents the isomerization-time curve of 0.05 molar DCS methanol solution. The measurements are based on gas chromatographic analysis.

For the isolation of the newly formed compound a $200 \mathrm{ml}$ methanol solution of $1.0 \mathrm{~g}$ of purified trans-DCS in a closed Erlenmeyer flask is exposed to sun-light until about $48 \%$ of the starting material has disappeared in the test gas chromatogram. This solution is evaporated to dryness and extracted once with $50 \mathrm{ml}$ and subsequently with $10 \mathrm{ml}$ propanol-2. The extract is concentrated to about $20 \mathrm{ml}$ and is chromatographed on a column filled with $100 \mathrm{~g}$ Sephadex LH-2O (Pharmacia, Uppsala, Sweden). The separation from the trans-DCS is achieved isothermally with water of $32^{\circ} \mathrm{C}$ circulating through the glass jacket of the chromatography column. For elution, the flow rate of propanol is regulated at about $3 \mathrm{ml}$ per hour. When about $80 \mathrm{ml}$ solvent have passed the column, the newly formed compound is eluted. It is clearly separated from the trans-DCS, which appears only after elution of $150 \mathrm{ml}$ propanol. (Separations on deactivated alumina do not give a satisfactory resolution, and partially. reconvert the new compound into the trans-form.) The residues of the filtered column fractions are recrystallized from methano] at $12^{\circ} \mathrm{C}$. After drying, the new compound $\left(350 \mathrm{mg}\right.$ ) has a melting point of $26-28^{\circ} \mathrm{C}$ and its $\mathrm{C}, \mathrm{H}, \mathrm{Cl}$-values correspond to those of a 4,4 '-dichlorostilbene.

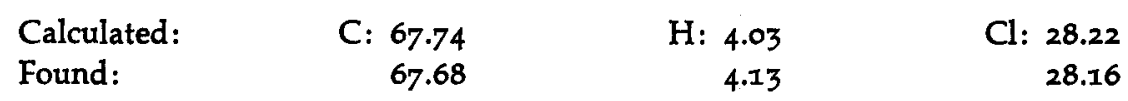

The elementary analyses were carried out by the Spang Microanalytical Laboratory, Ann Arbor, Michigan.

The configuration of cis-4,4'-dichlorostilbene is proved by a comparison of its infrared absorption spectrum with that of its trans-isomer (Fig. 2). The latter compound has a typical transethylene absorption band at $979 \mathrm{~cm}^{-1}$, whereas the new compound has two bands (780 and $876 \mathrm{~cm}^{-1}$ ) as expected for a cis-stilbene $(3,4)$.

Cigarette Tobacco

The tobacco of U.S. blended nonfilter cigarettes of $85 \mathrm{~mm}$ length and an average weight of $1.085 \mathrm{~g}$ per cigarette is dried to constant weight over calcium chloride and is extracted with dry benzene in a soxhlet. Analytical studies revealed a complete extraction of chlorinated insecticides during 48 hours. The residue obtained after 48 hours of extraction amounts to about $12 \%$ of the fresh, undried tobacco.

Cigarette Smoking

The cigarettes are conditioned in a humidity chamber, selected by weight and smoked under conditions previously reported (9). Smoking is done on single cigarette channels and the smoke is drawn through a trap immersed in dry ice-acetone and through a $250 \mathrm{ml}$ gas wash bottle with $50 \mathrm{ml}$ distilled water. Fifty cigarettes are smoked for each analysis.

Internal Standard

Seven micrograms of highly purified 1,1,1-trichloro-2,2-bis(p-chloropheny]-C ${ }^{14}[\mathrm{U}]$ )ethane (DDT-C ${ }^{14}$; $411,800 \mathrm{dpm}$; Nuclear (hicago) in $5 \mathrm{ml}$ cyclohexane are added as internal standard to the tobacco extract or smoke solution respectively. The Nuclear Chicago Scintillation System counted at an efficiency of $73.0 \%$ for the unquenched $C^{14}$-labelled DDT in toluene with $0.4 \%$ PPO (2.5-diphenyloxazole) and $0.005 \%$ POPOP (p-bis[2(5-phenyloxazolyl)])benzene as scintillators.

\section{Concentrating of Chlorinated Insecticides}

In order to enrich the chlorinated insecticides from the tobacco extract or tobacco smoke condensate the starting material plus internal standard are dissolved in methanol, water $(4: 1)$ and cyclohexane and are filtered. The lower layer is twice more extracted with an equal volume of preequilibrated upper phase. The combined upper phases are evaporated to dryness and 
FIGURE 3

A Separation scheme for chlorinated insecticides from cigarette smoke condensate Extractions

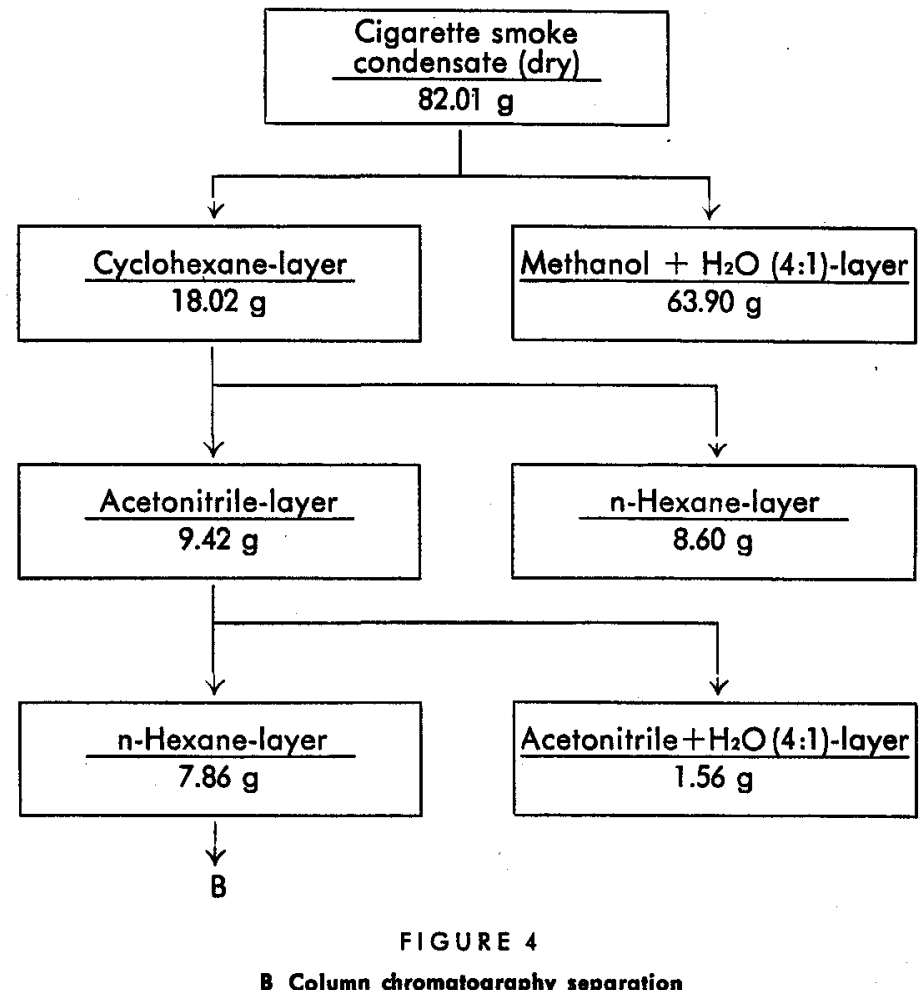

Column chromatography on alumina (rel. act. II) $(4,000 \mathrm{~g})$

\begin{tabular}{|c|c|c|}
\hline$\underset{\mathrm{n} \text {-hexane }}{1,000 \mathrm{ml}}$ & \multicolumn{2}{|r|}{ I $788.4 \mathrm{mg}$; no $\mathrm{Cl}$-insecticide } \\
\hline$\underset{\mathrm{n} \text {-hexane }}{\stackrel{200 \mathrm{ml}}{\longrightarrow}}$ & II & $56.3 \mathrm{mg}$; DCS \\
\hline$\frac{200 \mathrm{ml}}{\mathrm{n} \text {-hexane }} \rightarrow$ & III & $60.1 \mathrm{mg} ; \mathrm{DCS}+0, \mathrm{p}-\mathrm{DDT}+\mathrm{DDM}$ \\
\hline$\underset{\mathrm{n} \text {-hexane }}{\stackrel{500 \mathrm{ml}}{\longrightarrow}}$ & IV & $59.6 \mathrm{mg} ; \mathrm{DDM}+0, \mathrm{p}-\mathrm{DDT}$ \\
\hline$\underset{\text { hexane }+ \text { benzene }(4: 1)}{\stackrel{630 \mathrm{ml}}{\longrightarrow}}$ & V & $56.1 \mathrm{mg}$; DDT + DDM \\
\hline$\underset{\text { hexane }+ \text { benzene }(3: 1)}{\stackrel{500 \mathrm{ml}}{\longrightarrow}}$ & VI & $46.1 \mathrm{mg} ; \mathrm{DDD}+0, p-\mathrm{DDD}$ \\
\hline$\frac{50 \mathrm{ml}}{\text { hexane }+ \text { benzene }(2: 1)}$ & VII & $8.4 \mathrm{mg} ;$ DDD \\
\hline$\underset{\text { hexane }+ \text { benzene }(2: 1)}{\stackrel{50 \mathrm{ml}}{\longrightarrow}}$ & VIII & $6.9 \mathrm{mg} ; \mathrm{DDD}+\mathrm{m}, \mathrm{p}-\mathrm{DDD}$ \\
\hline$\underset{\text { hexane }+ \text { benzene }(2: 1)}{200 \mathrm{ml}}$ & IX & $15.5 \mathrm{mg}$; trace DDD \\
\hline $400 \mathrm{ml}$ & & $3,210 \mathrm{mg}$; no $\mathrm{Cl}$-insecticide \\
\hline
\end{tabular}


Partition coefficients of chlorinated insecticides

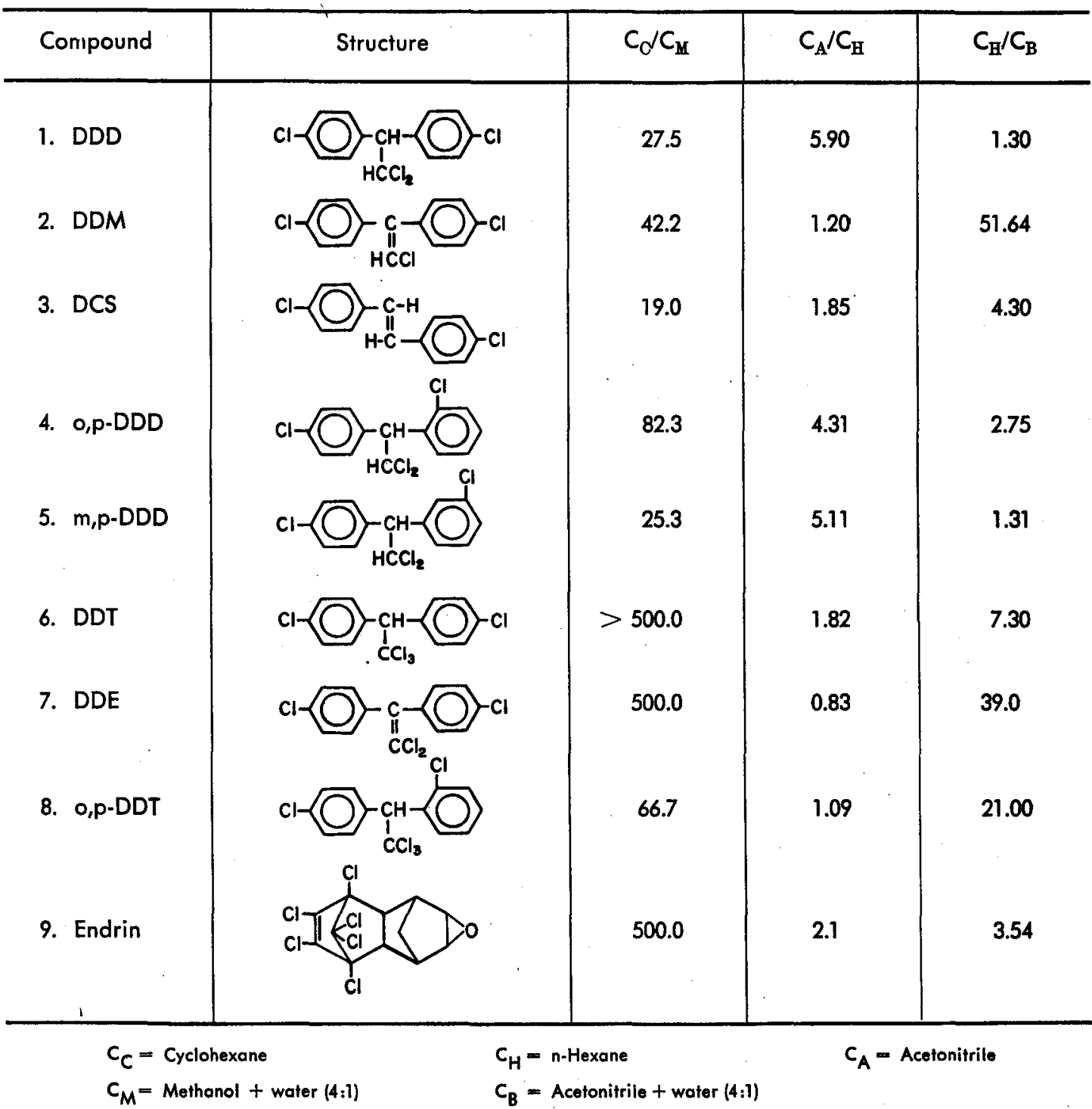

dissolved in $n$-hexane and acetonitrile. After separating of the layers, the upper phase is extracted three more times with preequilibrated acetonitrile. The combined acetonitrile layers are concentrated in vacuo and distilled water is added to this concentrate until a $4: 1$ acetonitrile water solution is reached. This phase is subsequently extracted four times with preequilibrated $n$-hexane. The partition coefficients of nine chlorinated hydrocarbons are given in Table 1 .

Since test runs demonstrated that deactivated alumina does not dehydrochlorinate DDD, DDT, and their isomers, aluminum oxide (Woelm, neutral, activity II) was used for the column chromatography in order to enrich the chlorinated insecticides. $\mathrm{N}$-hexane and $\mathrm{n}$-hexane, benzene were utilized as elution solvents. Since an electron capture detector has a high sensitivity for chlorinated hydrocarbons, especially for chlorinated insecticides $\left(\sim 10^{-12} \mathrm{~g}\right)$, samples of $I \mu \mathrm{l}$ or even less of the column fractions suffice for the gas chromatographic identification of the chlorinated hydrocarbons. An example of the enrichment of insecticides from cigarette smoke condensate is outlined in Figures 3 and 4. This large scale separation was necessary for the isolation and identification of individual chlorinated hydrocarbons. 


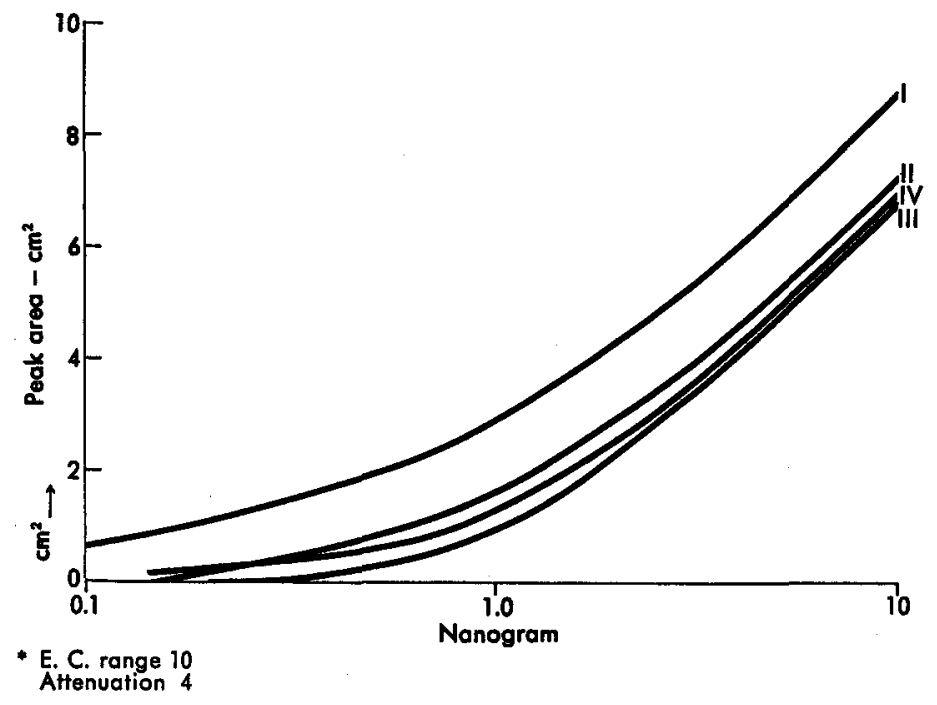

FIGURE 6

Linearity eurve for DDT [I]; O,P-DDT [II]; DCS [III]; DDE [IV]; and Endrin [V]*

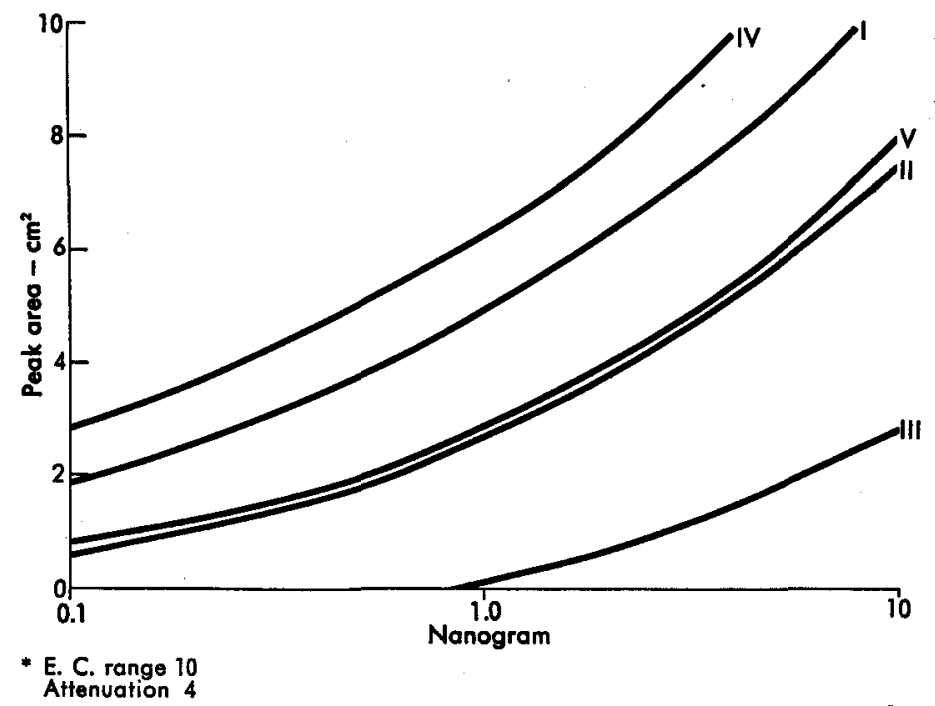

Gas Chromatography

For the quantitative analysis of chlorinated hydrocarbons in the column chromatography endfractions, we utilize a gas chromatograph with an electron capture detector (Varian AerographSeries 1200 with a tritiated titanium foil as source). The best separations of the chlorinated hydrocarbons in cigarette smoke can be achieved by using an about 1.7 meter long glass column with an inner diameter of $0.3 \mathrm{~cm}$, filled with an admixture of $7.5 \%$ Silicon QF-I (Wilkens Instruments and Research, Walnut Creek, California) and 5\% DC-20o on Gas Chrom Q, 80-100 mesh (both from Applied Science Laboratories, State College, Pennsylvania). The temperature at the injection block is held at $240^{\circ} \mathrm{C}$. The nitrogen flow is kept at $30 \mathrm{ml}$ per minute. The sensitivity of the detector system to various chlorinated insecticides is graphically expressed in Figures 5 and 6 . Using this setting we avoided any detectable degradation of the chlorinated insecticides studied here.

At the end of the quantitative analysis three I- $\mu$ l-aliquots of the concentrate of insecticides are analyzed by gas chromatography. For liquid scintillation counting three samples of each concentrate are taken. Each aliquot must have an activity of at least $50,000 \mathrm{dpm}$. The average values 
from both measurements are taken for the calculation of quantitative data for the concentration of individual insecticides.

For isolating and identifying insecticides and other chlorine containing agents in the chromatography fractions we use a Perkin-Elmer gas chromatograph 800 with hydrogen flame ionization detector and glass splitter with a $4: 1$ ratio. The actual separation is achieved on a $0.6 \mathrm{~cm}$ glass column of $2 \mathrm{~m}$ length, which is filled with the stationary system described above. With this setting it is guaranteed that the injected material after passing the injection block will not contact metal parts of the instrument.

\section{Identification of Insecticides}

Those components of the column chromatography fractions that elicit a significant response of the electron capture detector are collected in capillary glass tubes. Owing to the splitter ratio $80 \%$ of the separated material can be obtained in this manner. A specific component in the effluent may have to be collected between 3-10 times, depending on its concentration in the injected solution, in order to yield sufficient material for mass spectrometric analysis. The mass spectra were carried out by the Morgan-Schaffer Corporation in Montreal, Canada, with a Hitachi Perkin-Elmer R.M.U.-6D instrument.

RESULTS

\section{Qualitative Analysis}

For the gas chromatographic identification of chlorinated insecticides we used individual column chromatography endfractions (Fig. 3 and 4 ) and combined aliquots of the fractions (Fig. 7 and 8). The isolation of these components was achieved by separately injecting the endfractions into the gas chromatograph with a $4: 1$ splitter and ionization detector. The combined effluents of

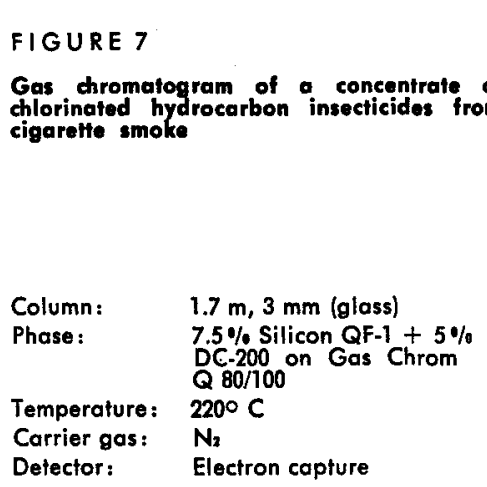

FIGURE 8

Gas chromatogram of a concentrate of chlorinated hydrocarbon insecticides from cigarette smoke

$\begin{array}{ll}\text { Column: } & 2 \mathrm{~m}, 6 \mathrm{~mm} \text { (glass) } \\ \text { Phose: } & 7.5 \% \text { Silicon QF-1 }+5 \% \\ & \text { DC-200 on Gas Chrom } \\ \text { Temperature: } & 220 \% 100 \\ \text { Carrier gas : } & \text { Helium } \\ \text { Detector: } & \text { Flame lonization }\end{array}$
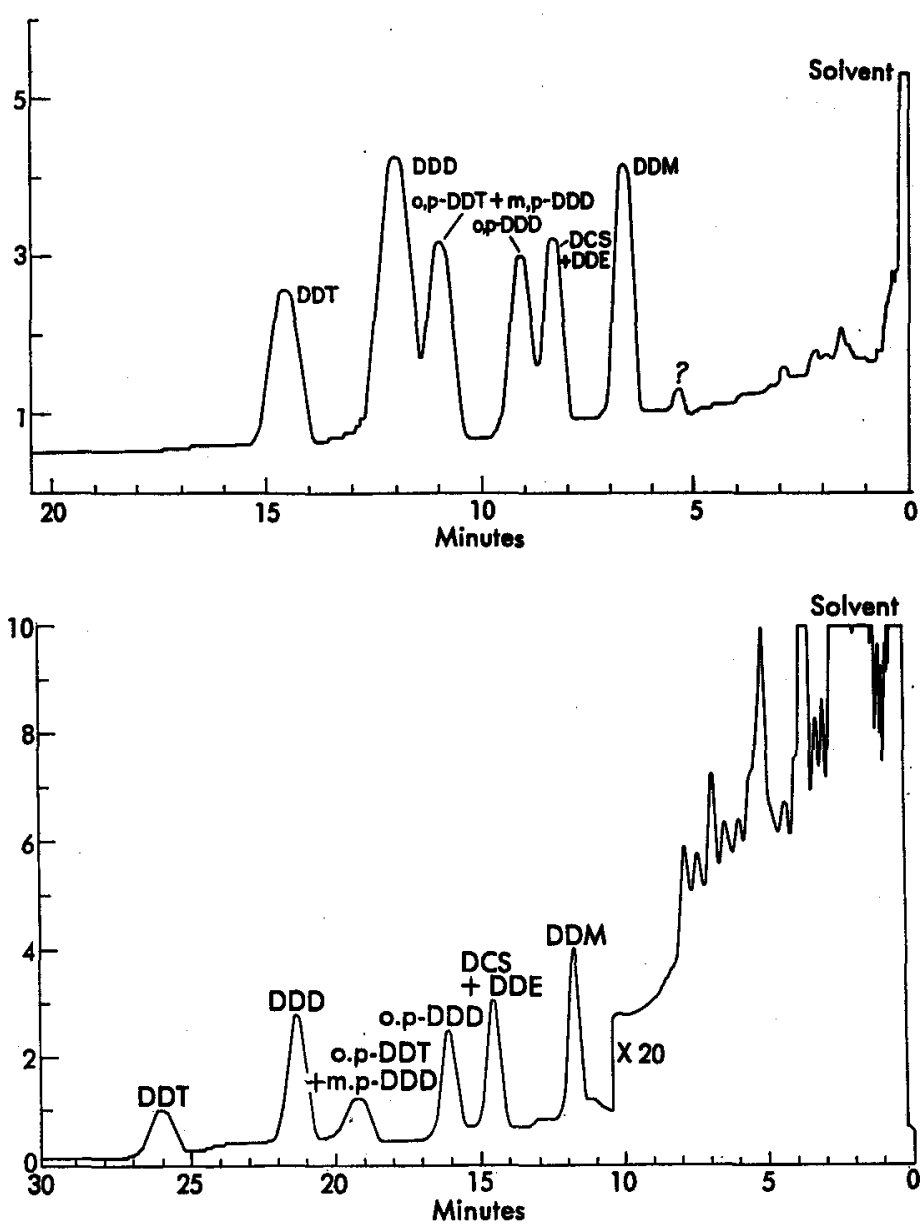
FIGURE ?

IOnly the main fragments are shown.)
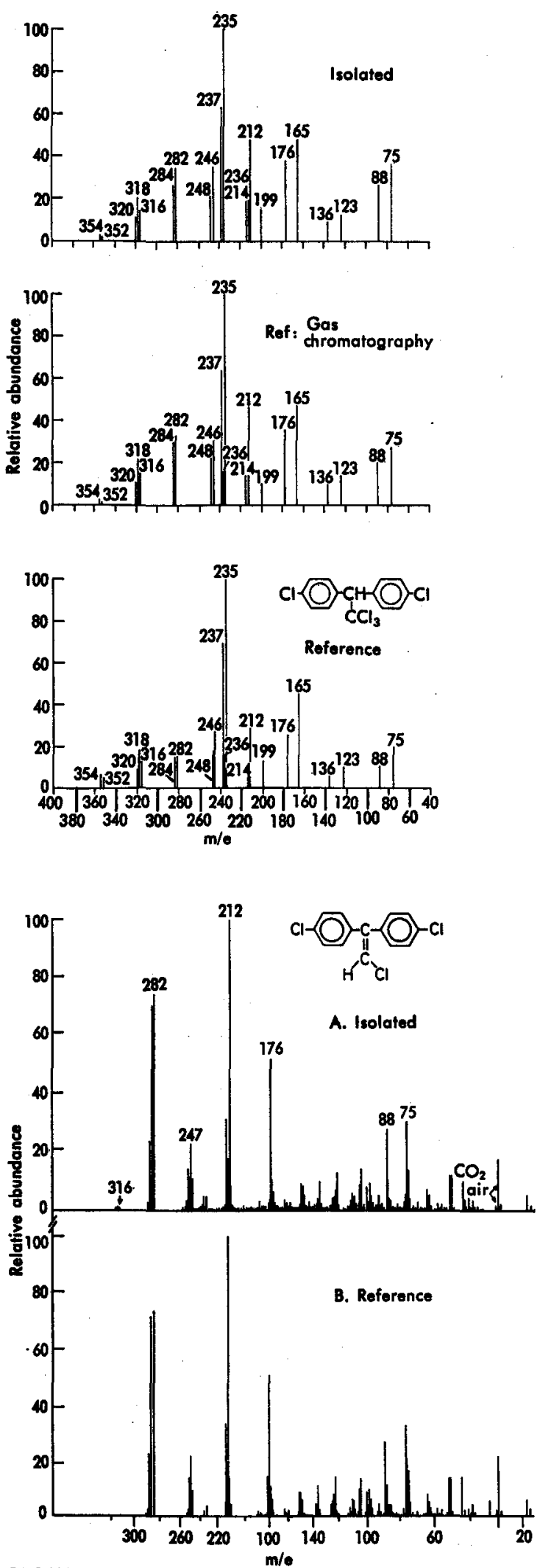

FIGURE 11
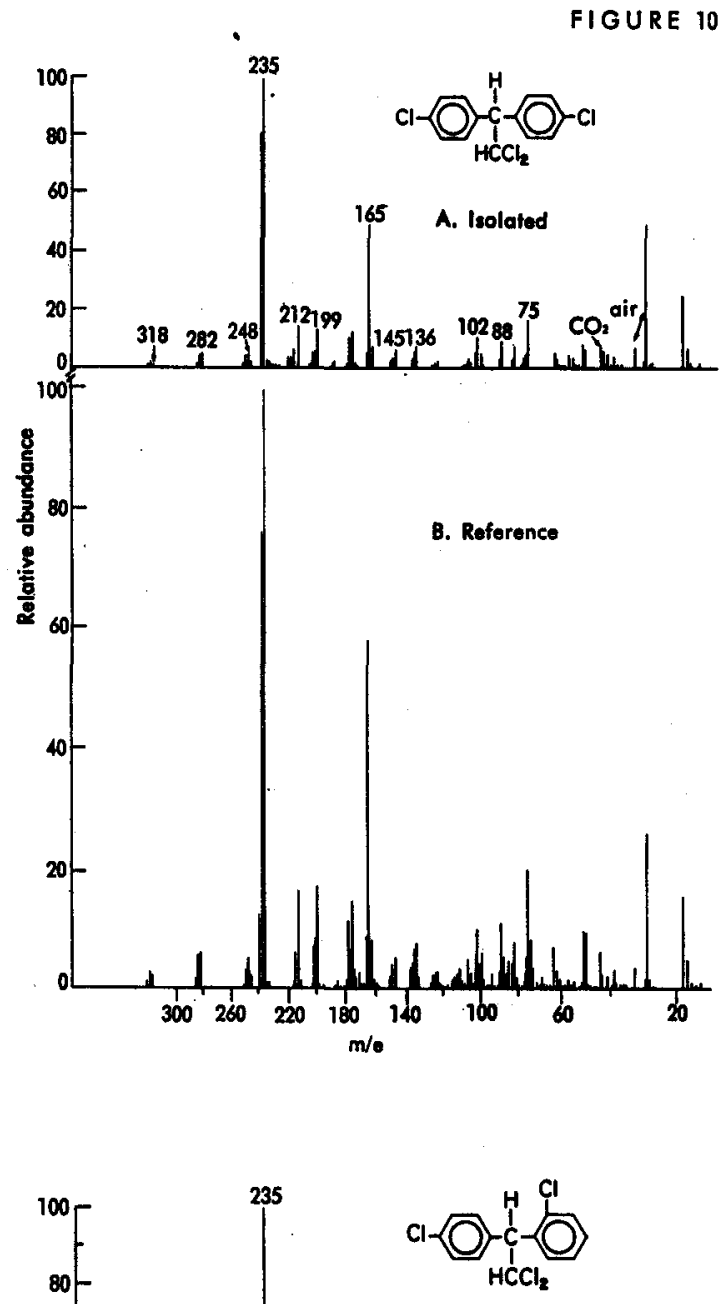

A. Isolated
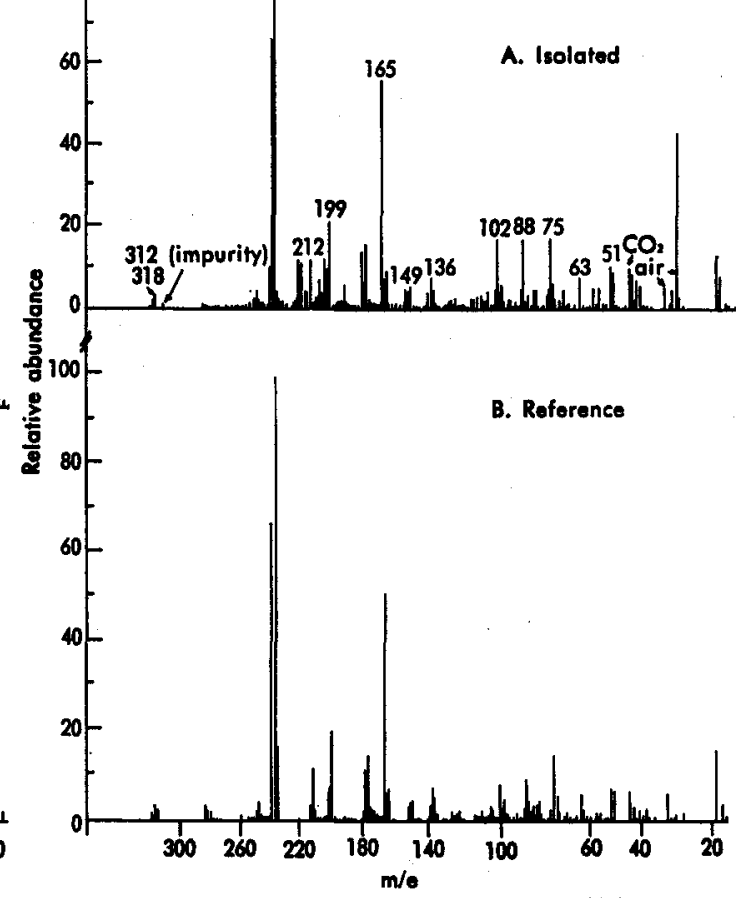
FIGURE 13

(Only the main fragments are shown.)
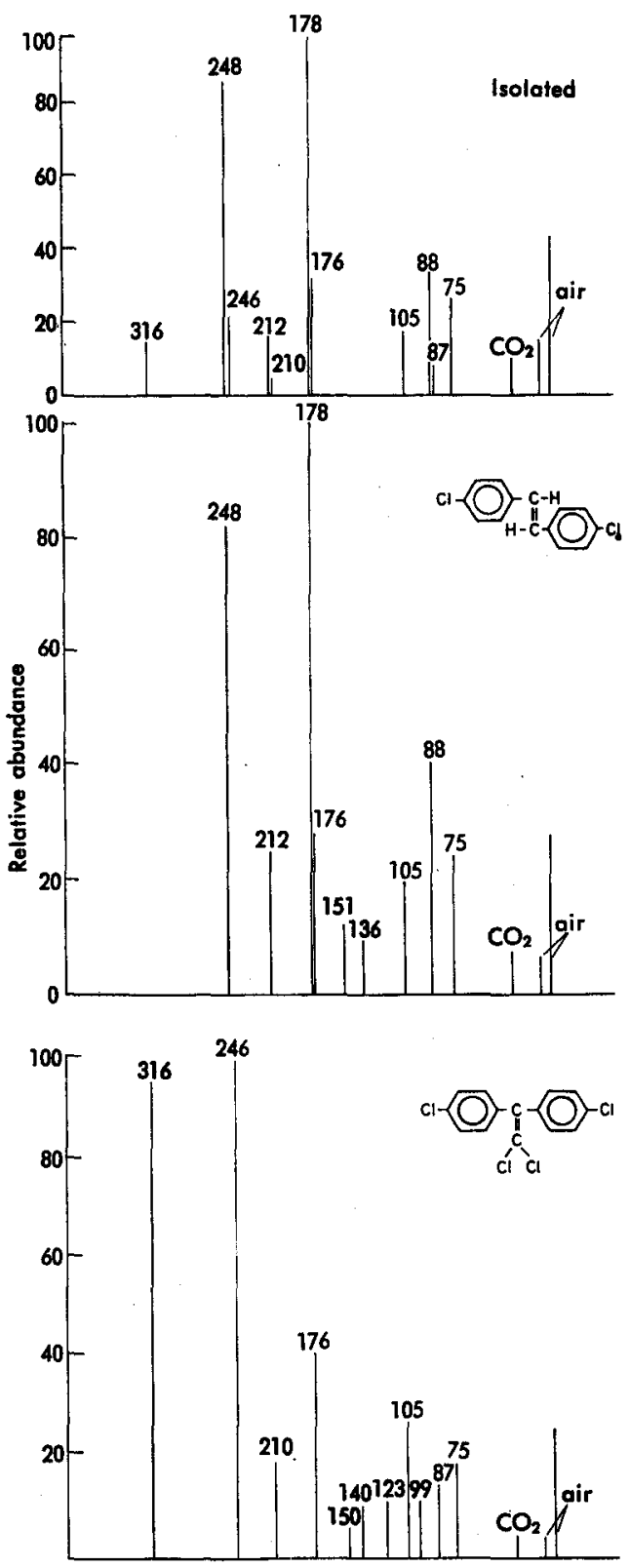

$\mathrm{m} / \mathbf{e}$

3-10 runs corresponding to a given peak were collected in glass capillaries and then used for mass spectrometric analysis. The relative abundance of the $3,4,5$ or 6 parent ions for each Cl-component as given by the isotope distribution of $\mathrm{Cl}^{35}$ and $\mathrm{Cl}^{37}$ (17) are used for determining the number of $\mathrm{Cl}$-atoms in the molecule, and its molecular weight. These data, the fragmentation pattern in the mass spectra and the gas chromatographic data served for the identification of individual components in cigarette smoke and cigarette tobacco. In this manner we identified DDT, DDD and DDM as well as o,p-DDD (Figures 9-12). Two peaks in the gas chromatograms were identified as admixtures. These were DCS plus DDE (Fig. 13), and $m, p$-DDD plus o,p-DDT (Fig. 14). The ratio of the first pair could be determined by taking a sample from the gas chromatographic separation and by preparation of ultraviolet absorption spectra (Fig. 15) and gas chromatograms of their aliquots. The first method gives the quantity of DCS, the second method the amount of DCS plus DDE. Thus, the concen- 


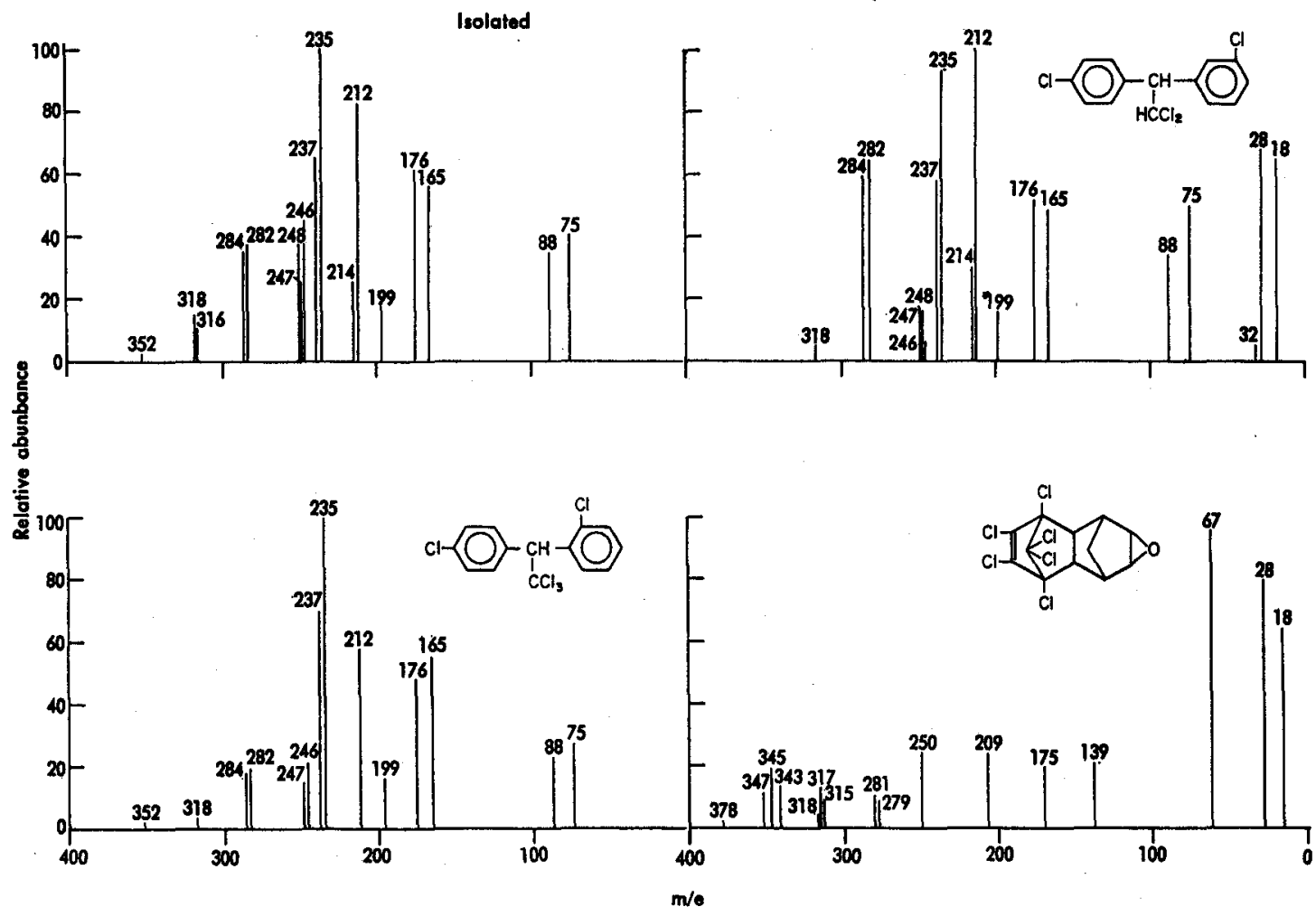

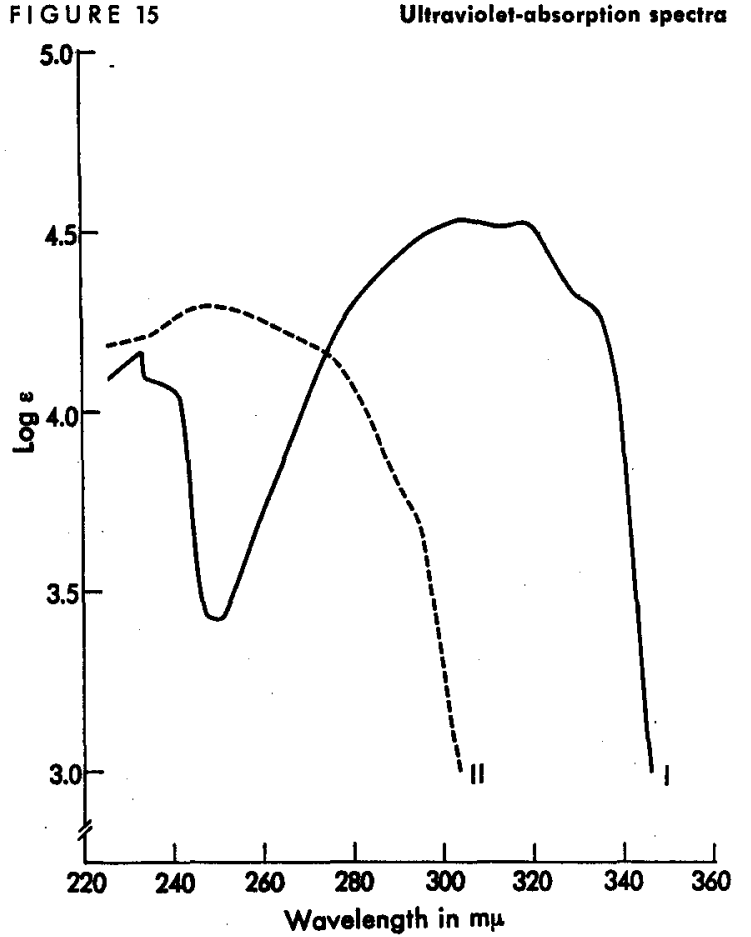

1 Trans-4,4'-dichlorostilbene [DCS]

II 1,1-Dichloro-2,2-bis(p-chlorophenyl)ethylene [DDE] Solvent $=$ cyclohexane tration of DDE appears as the difference between the two values. For the U.S. $85 \mathrm{~mm}$ cigarette $80 \pm 10 \%$ of the admixture was given by DCS, the remainder by DDE.

DDD, DDT and their isomers give only low abundances for their parent ions, indicating relatively low stability of these components at increased temperatures. In the case of DDT the relative abundances of the parent ions after collecting the material corresponding to the DDT-retention time were lower than those of purified DDT obtained by recrystallization (Fig. 9). This observation indicates that the partial dehydrochlorination occurs on the column material itself. Pure DDT, however, could be isolated from a column fraction of a large sample (Fig. 3 and 4 ) by chromatography on Sephadex LH-20 at $32^{\circ} \mathrm{C}$ with propanol-2 as elution solvent. Exhaustive efforts to isolate endrin from tobacco or from the smoke samples were fruitless.

Quantitative Analysis

Table 2 presents the quantitative data for chlorinated aromatic hydrocarbons in the mainstream smoke of an $85 \mathrm{~mm}$ nonfilter cigarette. The experimental deviation based on five tests varied between $3.4 \%-8.8 \%$ depending on the concentration of the individual components or admixture of two components. The DCS-peak is constituted of about $80 \%$ DCS and $20 \%$ DDE. 
Chlorinated insecticides in cigarefte mainstream smoke *

\begin{tabular}{l|c|c|c|c|c|c|c|c}
\hline & $\begin{array}{c}\mathrm{I} \\
\mu \mathrm{g} / \mathrm{cig} .\end{array}$ & $\begin{array}{c}\mathrm{II} \\
\mu \mathrm{g} / \mathrm{cig} .\end{array}$ & $\begin{array}{c}\mathrm{III} \\
\mu \mathrm{g} / \mathrm{cig} .\end{array}$ & $\begin{array}{c}\mathrm{IV} \\
\mu \mathrm{g} / \mathrm{cig} .\end{array}$ & $\begin{array}{c}\mathrm{V} \\
\mu \mathrm{g} / \mathrm{cig} .\end{array}$ & $\begin{array}{c}\text { Average } \\
\mathrm{m}\end{array}$ & $\begin{array}{c}\text { Standard } \\
\text { deviation }\end{array}$ & $\begin{array}{c}\text { Deviation } \\
\text { coefficient }\end{array}$ \\
\hline DDM & 0.76 & 0.84 & 0.82 & 0.82 & 0.80 & 0.81 & 0.034 & $4.2 \%$ \\
DCS $^{1}$ & 1.76 & 1.73 & 1.78 & 1.67 & 1.71 & 1.73 & 0.043 & $2.5 \%$ \\
O,p-DDD & 0.40 & 0.42 & 0.47 & 0.46 & 0.50 & 0.45 & 0.040 & $8.8 \%$ \\
O,p-DDT & 0.68 & 0.72 & 0.69 & 0.67 & 0.73 & 0.70 & 0.026 & $3.7 \%$ \\
DDD & 1.70 & 1.72 & 1.78 & 1.73 & 1.85 & 1.75 & 0.060 & $3.4 \%$ \\
DDT & 0.77 & 0.84 & 0.71 & 0.76 & 0.79 & 0.77 & 0.048 & $6.2 \%$ \\
\hline
\end{tabular}

* For each determinction - 50 cigarettes were smoked under standard conditions (9).

$121 \%$ of the trans-4,4'-dichlorostilbene peak is made up by DDE.

The qualitative and quantitative findings for chlorinated insecticides in tobacco are summarized in Table 3. As can be seen in Table 4, BI contains only a certain proportion of these insecticides since originally the whole separation scheme was based solely on the requirement to concentrate the polynuclear aromatic hydrocarbons $(\mathrm{PAH})$ of cigarette smoke condensate in one fraction. This fraction naturally contains also components other than $\mathrm{PAH}$, but if some of these are quantitatively enriched in $\mathrm{BI}$, this is incidental.

The concentration of chlorinated insecticides in one fraction for the gas chromatographic analysis was accomplished with losses between $10-20 \%$.

Table 5 lists the transfer rate of DDD, DDT, and their isomers from tobacco into the mainstream smoke. The findings for DDD and DDM are in agreement with those earlier reported by Guthrie and Bowery (5) showing a recovery of $10-20 \%$.

TABLE 3

Chlorinated insecticides in tobacco

\begin{tabular}{cc}
\hline \multicolumn{2}{c}{$\begin{array}{c}\text { per } 1 \mathrm{~g} \\
\text { of } \begin{array}{c}\text { tobacco* } \\
(\mu \mathrm{g})\end{array}\end{array}$} \\
\hline DDM & 1.1 \\
0, p-DDD & 4.8 \\
DDD & 11.7 \\
0, p-DDT & 3.55 \\
DDT & 7.8 \\
\hline
\end{tabular}

* $11.2 \%$ moisture content.

\begin{tabular}{|cc|c|}
\multicolumn{3}{|c|}{$\begin{array}{c}\text { TA B LE 4 } \\
\text { Chlorinated insecticides } \\
\text { in subfraction BI }\end{array}$} \\
\cline { 3 - 3 } & & $\begin{array}{c}\text { Percent of insecti- } \\
\text { cides from amount } \\
\text { in total smoke } \\
\text { condensate* }\end{array}$ \\
\hline DDM & $0.03 \%$ & 6.4 \\
DCS & $0.51 \%$ & 51.7 \\
o, p-DDD & traces & - \\
DDD & $0.54 \%$ & 54.1 \\
DDT & $0.13 \%$ & 29.6 \\
o, p-DDT & $0.01 \%$ & 2.4 \\
\hline . Calculated from the results in Table 2
\end{tabular}

TABLE 5

Transfer rate of chlorinated insecticides from cigarette tobacco into mainstream smoke

\begin{tabular}{c|c}
\hline Insecticide & $\begin{array}{c}\text { Transfer } \\
\text { rate \% }\end{array}$ \\
\hline DDD & 18.0 \\
o, p-DDD & 11.6 \\
DDT & 12.4 \\
\hline DDM* & $(67.4)$ \\
\hline DDM is mainly formed from DDD \\
during smoking; however, a small \\
portion of it derives from the DDM \\
already present in the tobacco.
\end{tabular}

"Aging" of tobacco smoke condensate

Figure 16 presents the gas chromatogram of a solution of a concentrate of chlorinated aromatic hydrocarbons from cigarette mainstream smoke, which we exposed for one week to the radiation of white fluorescent lamps as installed in most laboratories. The new peak, absent in samples

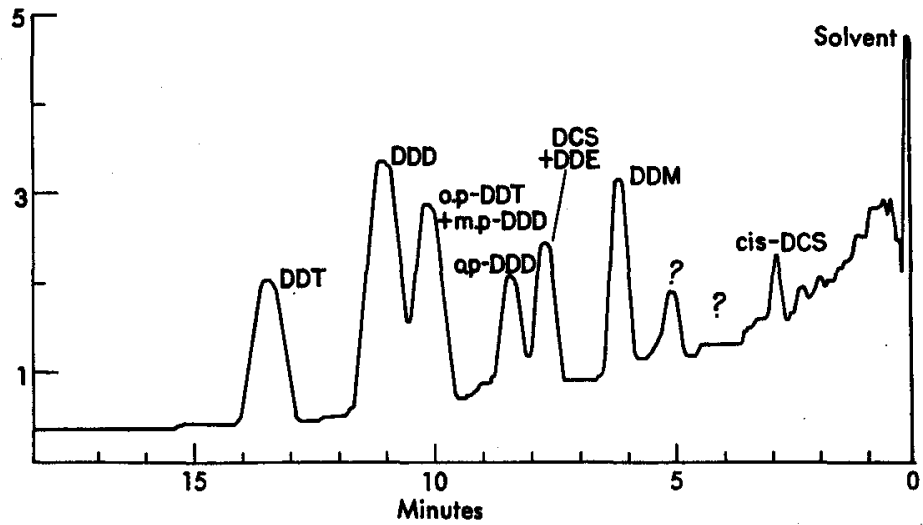
from laboratories illuminated with yellow lamps, was identified as cis-4,4'-dichlorostilbene and its occurrence in tobacco smoke condensate must be considered an artefact due to "aging", or, more appropriately, photoisomerization. 
A blended U.S. cigarette tobacco dating from 1967 contains DDD, o,p-DDD, m,p-DDD, DDT, and a trace of the DDD-dehydrochlorination product DDM. Despite exhaustive search we were unable to identify endrin, another tobacco insecticide frequently used in the past on tobacco. This result stands in contrast to earlier findings, however, it should be recalled that according to a 1964 regulation of the U.S. Department of Agriculture, endrin is banned for the use in domestic tobacco (20).

The mainstream smoke contains not only the insecticides already present in the tobacco, but a significantly higher concentration of DDM and DDE, as well as trans-4,4'-dichlorostilbene [DCS]. DDM respectively DDE are formed by dehydrochlorination of DDD and DDT. It appears not unlikely that DCS is formed from DDD and DDT in the reducing environment of the burning cone of a cigarette. This hypothesis is supported by the isolation of DCS as a reduction product of DDT and DDD in ethanolic hydrochloric acid (4). $L i$ pyrolyzed 1,1-diphenylethane in nitrogen at $600-700^{\circ} \mathrm{C}$ together with a dehydrogenation catalyst $(\mathrm{Ni}$ or $\mathrm{ZnO})$ and isolated stilbene as a rearrangement product of the starting material (12). Ramat-Lucas and Amagat pyrolyzed 1,1-diphenylethylene on siliceous earth and isolated stilbene (16). Based on these data it appears likely that in the burning cone of a tobacco product DDT and DDD are partially dehydrochlorinated, hydrogenated and rearranged to trans-4,4'-dichlorostilbene. However, this hypothesis needs to be substantiated by further pyrolysis experiments.

'In view of the experienced photoisomerization of trans-DCS, it is conceivable that cis-4,4'-DCS may undergo further photorearrangements and photooxidations. We are currently investigating this possibility.

Our interest in chlorinated hydrocarbon insecticides has been motivated by their presence in the tumorigenic subfraction BI of cigarette smoke condensate. Recently, there has been some concern about the possible importance of chlorinated insecticides in tobacco carcinogenesis (18). It has been suggested that the liver detoxification of PAH by hydroxylation is inhibited by insecticides and thus the exposure of the target organs to the carcinogenic hydrocarbons is increased (6). However, our experiences indicate that such a mechanism is not likely to play a role in mouse skin carcinogenesis. A direct effect of insecticides on the epithelial cell constituents appears to us the more obvious one. We are investigating such a possible influence in ongoing studies. At present we know of no evidence which indicates a contributing role of chlorinated insecticides to experimental tobacco carcinogenesis.

\section{SUMMARY}

An analytical method was developed for the qualitative and quantitative determination of chlorinated hydrocarbon insecticides in tobacco products. It is based on three consecutive distributions, followed by column chromatography on deactivated alumina. This procedure leads to a degree of enrichment which allows the direct assessment of the insecticides by gas chromatography. For the isolation and identification of the individual components the column chromatography endfractions are separated by gas chromatography and collected from the effluent of the column. These materials are used for mass spectrometric analyses. For the quantitative analyses DDT-C ${ }^{14}$ is used as internal standard and the amount of insecticides is determined with the aid of a gas chromatograph with electron capture detector.

In $1.0 \mathrm{~g}$ cigarette tobacco were found $11.7 \mu \mathrm{g}$ 1,1-dichloro-2,2-bis(p-chlorophenyl)ethane [DDD]; $4.8 \mu \mathrm{g}$ 1,1-dichloro-2-(o-chlorophenyl)-2-(p-chlorophenyl)ethane [o,p-DDD]; $1,1 \mu \mathrm{g}$ I-chloro-2,2bis(p-chlorophenyl)ethylene [DDM] ; $7.8 \mu \mathrm{g}$ 1,1,1-trichloro-2,2-bis(p-chlorophenyl)ethane [DDT] and $3.6 \mu \mathrm{g}$ of an admixture of 1,1,1-trichloro-2-(o-chlorophenyl)-2-(p-chlorophenyl)ethane [0,p-DDT] and 1,1 -dichloro-2-(m-chlorophenyl)-2-(p-chlorophenyl)ethane [ $m, p-D D D]$. The mainstream smoke of an $85 \mathrm{~mm}$ U.S. blended cigarette without filter tip contained $1.75 \mu \mathrm{g}$ DDD, $0.45 \mu \mathrm{g}$ o,p-DDD, $0.81 \mu \mathrm{g}$ DDM, $0.77 \mu \mathrm{g}$ DDT, $0.70 \mu \mathrm{g}$ o,p-DDT plus m,p-DDD, $0.21 \mu \mathrm{g}$ 1,1-dichloro-2-2-bis(pchlorophenyl)ethylene and $1.52 \mu \mathrm{g}$ trans-4,4'-dichlorostilbene. Endrin was detected neither in cigarette smoke nor in U.S. tobaccos of Winter 1967-68. The transfer rates for unchanged 
chlorinated insecticides from cigarette tobacco into mainstream smoke amounted to $18 \%$ for DDD, $11.6 \%$ for o,p-DDD and $12.4 \%$ for DDT.

The findings of this study are compared with earlier publications and are briefly discussed in respect to formation of some of the chlorinated aromatic hydrocarbons and the possible, though rather unlikely, contribution of chlorinated hydrocarbon insecticides to experimental tobacco carcinogenesis.

ZUSAMMENFASSUNG

Die vorliegende Arbeit beschreibt eine Methode zur qualitativen und quantitativen Analyse von chlorhaltigen Insektiziden in Tabakprodukten. Der analytische Trennungsgang beginnt mit der Verteilung des Tabakextraktes oder Rauchkondensates zwischen drei Lösungspaaren und wird gefolgt von einer weiteren Anreicherung der Insektizide durch Säulenchromatographie an inaktiviertem Aluminiumoxyd. Durch diese Methode sind die Insektizide genügend konzentriert, um direkt von den Chromatographiefraktionen gaschromatographisch bestimmt $\mathrm{zu}$ werden. Die Isolierung der Insektizide erfolgt durch Gaschromatographie, ihre Identifizierung durch massenspektroskopische und gaschromatographische Analyse. Quantitative Ergebnisse werden durch die Anwendung von

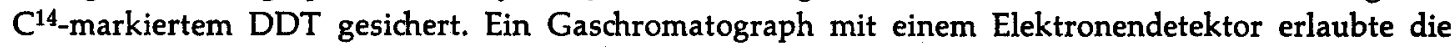

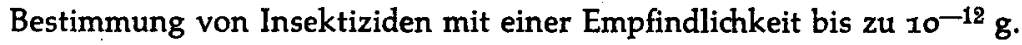

In einem Gramm eines Cigarettentabakes wurden die folgenden chlorierten Insektizide gefunden: $11,7 \mu \mathrm{g}$ 1,1-Dichlor-2,2-di(p-chlorphenyl)äthan [DDD]; 4,8 $\mu \mathrm{g}$ 1,1-Dichlor-2-(o-chlorphenyl)-2-(pchlorphenyl)äthan [0,p-DDD]; 1,1 $\mu \mathrm{g}$ 1-Chlor-2,2-di(p-chlorphenyl)äthylen [DDM]; 7,8 $\mu \mathrm{g} 1,1,1-$ Trichlor-2,2-di(p-chlorphenyl)äthan [DDT] und $3,6 \mu \mathrm{g}$ eines Gemisches von 1,1,1-Trichlor-2-(ochlorphenyl)-2-(p-chlorphenyl)äthan [o,p-DDT] und 1,1-Dichlor-2-(m-chlorphenyl)-2-(p-chlorphenyl)äthan [m,p-DDD]. Der Hauptstrom des Rauches einer $85 \mathrm{~mm}$ langen filterlosen Cigarette enthielt 1,75 $\mu \mathrm{g}$ DDD; 0,45 $\mu \mathrm{g}$ 0,p-DDD; 0,81 $\mu \mathrm{g}$ DDM; 0,77 $\mu \mathrm{g}$ DDT; 0,70 $\mu \mathrm{g}$ o,p-DDT und m,p-DDD; $0,21 \mu \mathrm{g}$ I,I-Dichlor-2,2-di(p-chlorphenyl)äthylen und 1,52 $\mu \mathrm{g}$ Trans-4,4'-dichlorstilben. Endrin konnte weder im Cigarettenhauptstrom noch im Tabak nachgewiesen werden. Die Anteile der chlorierten Insektizide, die unzersetzt in den Hauptstrom einer Cigarette überführt werden, betrugen $18 \%$ für DDD, $11,6 \%$ für $0, p$-DDD und $12,4 \%$ für DDT.

Die Befunde dieser Untersuchung werden mit denen aus früheren Publikationen verglichen. Die Bildung einiger der chlorierten aromatischen Kohlenwasserstoffe und der mögliche, doch recht unwahrscheinliche Beitrag der Organo-Chlor-Insektizide zur experimentellen Karzinogenese durch Tabakrauch werden kurz erörtert.

RESUME

Le présent travail décrit une méthode analytique pour la détermination qualitative et quantitative $\mathrm{d}$ 'insecticides organo-chlorés dans des produits de tabac. L'analyse comporte les étapes suivantes: Trois distributions consécutives de l'extrait de tabac ou du condensat de fumée suivies de la chromatographie sur colonne d'oxyde d'aluminium inactivé. Le degré d'enrichissement ainsi atteint suffit pour la détermination directe des insecticides par chromatographie gazeuse dans les fractions chromatographiques. L'isolement des composants individuels se fait par la séparation des fractions finales de la chromatographie sur colonne moyennant la chromatographie gazeuse. Les effluents correspondant aux pics chromatographiques sont ensuite identifiés par spectroscopie de masse et par chromatographie gazeuse. Dans le but d'obtenir des résultats quantitatifs assurés, on a utilisé comme standard interne le DDT marqué au $C^{14}$. L'application de la chromatographie gazeuse en conjonction avec la détection par capture d'électrons permet d'estimer les insecticides avec la limite de sensibilité de $10^{-12} \mathrm{~g}$.

Dans 1,0 gramme de tabac de cigarette on a trouvé $11,7 \mu \mathrm{g}$ de 1,1-dichloro-2,2-bis(p-chlorophényl)éthane [DDD]; 4,8 $\mu \mathrm{g}$ de 1,1-dichloro-2-(o-chlorophényl)-2-(p-chlorophényl)éthane [o,p-DDD]; $1,1 \mu \mathrm{g}$ de 1-chloro-2,2-bis(p-chlorophényl)éthylène [DDM]; 7,8 $\mu \mathrm{g}$ de 1,1,1-trichloro-2,2-bis(pchlorophényl)éthane [DDT] ainsi que $3,6 \mu \mathrm{g}$ d'un mélange additionnel de $1,1,1$-trichloro-2-(o-chlorophényl)-2-(p-chlorophényl)éthane [o,p-DDT] et 1,1-dichloro-2-(m-chlorophényl)-2-( $\mathrm{p}$-chlorophényl)éthane $[\mathrm{m}, \mathrm{p}-\mathrm{DDD}]$. Le flux principal de la fumée d'une cigarette américaine de $85 \mathrm{~mm}$, sans filtre, 
contenait 1,75 $\mu \mathrm{g}$ de DDD; 0,45 $\mu \mathrm{g}$ de o,p-DDD; 0,81 $\mu \mathrm{g}$ de DDM; 0,77 $\mu \mathrm{g}$ de DDT; $0,70 \mu g$ de $0, p-D D T$ phus $\mathrm{m}, \mathrm{p}$-DDD; $0,21 \mu \mathrm{g}$ de 1,1-dichloro-2,2-bis(p-chlorophényl)éthylène et 1,52 $\mu \mathrm{g}$ de trans$4,4^{\prime}$-dichlorostilbène. La présence de l'eldrine n'a pu être détectée ni dans le flux principal de la fumée de cigarette ni dans des tabacs américains de l'hiver 1967-1968. La part des insecticides chlorés qui se transfère dans le flux principal de la fumée sans changer se monte aux taux suivants: $18 \%$ pour le DDD; $11,6 \%$ pour le o,p-DDD et $12,4 \%$ pour le DDT.

On compare les résultats obtenus à ceux publiés auparavant et en discute brièvement du point de vue de la formation de certains des hydrocarbures aromatiques chlorés en question ainsi que du point de vue de la contribution possible, mais peu vraisemblable d'insecticides organo-chlorés à la tumorigénicité expérimentale du tabac.

REFERENCES

1. Bowery, T. G., Gatterdam, P. E., Guthrie, F. E., and Rabb, R. L.: J. Agr. Food Chem. 13 (1965) 356.

2. Brizer, E., Dallwigk, E., and Rucca, M.: Helv. Chim. Acta 41 (1958) 1390.

3. DeTar, D. F., and Caprino, L. A.: J. Am. Chem. Soc. 78 (1956) 475.

4. Forrest, J., Stephenson, O., and Waters, W. A.: J. Chem. Soc. (1946) 333.

5. Guthrie, F. E., and Bowery, T. G.: Residue Rev. 19 (1967) 31.

6. Falk, H. L., Thompson, S. J., and Kotin, P.: Arch. Environ. Health 1o (1965) 847.

7. Haller, H. L., Bartlett, P. D., Drake, N. L., Newman, M. S., Cristol, S. J., Eaker, C. M., Hayes, R. A., Kilmer, G. W., Magerlein, B., Müller, G. P., Schneider, A., and Wheatley, W. J.: J. Am. Chem. Soc. 67 (1945) 1591.

8. Harris, C. R., Sans, W. W., and Milles, J. R. W.: J. Agr. Food Chem. 14 (1966) 398.

9. Hoffmann, D., and Rubin, J.: Beitr. Tabakforsch. 3 (1956) 409.

10. Hoffmann, D., and Wýnder, E. L.: Proc. Am. Assoc. Cancer Res. 7 (1966) 32.

11. Hoffmann, D., and Wynder, E. L.: Monogr. Natl. Cancer Inst. 28 (1968) in press.

12. Li, H. Y.: J. Chem. Soc. Japan 62 (I94I) 562.

13. Lutz, R. E., and Murphey, R. S.: J. Am. Chem. Soc. 71 (1949) 478.

14. Marth, E. H.: J. Milk Food Technol. 25 (1962) 36.

15. Mold, J. D., and Walker, T. B.: Tobacco Sci. 1 (1957) 161.

16. Ramart-Lucas, Mme., and Amagat, P.: Bull. Soc. Chem. 51 (1932) 108.

17. Reed, R. I.: Advan. Org. Chem. 3 (1963) I.

18. Rept. of the Advisory Comm. to the Surgeon Gen. on Smoking and Health: Publ. Health Serv. Publ. 1103 (1964) 145.

19. Tappan, W .B., Van Middlem, C. H., and Moye, H. A.: J. Econ. Entomol. 60 (1967) 765.

20. U.S. Department of Agriculture: Chem. Eng. News 42 (1964) 21.

21. Wynder, E. L., and Hoffmann, D.: Tobacco and Tobacco Smoke, Studies in Experimental Carcinogenesis (1967), Academic Press, New York.

Authors' address:

Sloan-Kettering Institute for Cancer Research, 410 East 68th Street, New York, N. Y., 10021, USA 